\title{
Effect of pinocembrin pre-treatment on expressions of Cx43 protein and claudin 1 in myocardial ischemia cardiomyocytes of arrhythmic rats
}

\author{
Guang-ming Zhang ${ }^{1 *}$, Zhi-ying Zhao ${ }^{2}$, Hai-juan $\mathrm{Hu}^{1}$, Jing Yang ${ }^{1}$, Guoqiang Gu ${ }^{1}$ \\ ${ }^{1}$ Department of Cardiology, The Second Hospital of Hebei Medical University, Shijiazhuang, Hebei 050000, ${ }^{2}$ Department of \\ Pharmacology, Hebei Medical University, Shijiazhuang, Hebei 050017, PR China
}

*For correspondence: Email: guangmzhang@163.com

\begin{abstract}
Purpose: To investigate the effects of pinocembrin on ventricular rhythm and the expression of cardiomyocyte ligament junction protein (Cx43) and claudin 1 (ZO-1) in ischemia/reperfusion (I/R) rats. Methods: Ischemia/reperfusion (I/R) model rats $(n=15)$ were divided into 5 groups: IR group, control group, and 3 pinocembrin groups $(3,10$ and $30 \mathrm{mg} / \mathrm{kg})$. The serum levels of creatine kinase-MB isoenzyme (CK-MB) and troponin I (cTnl) were measured by enzyme-linked immunosorbent assay (ELISA). Changes in myocardial tissue were detected by $H$ \& E staining, while $M R N A$ and protein levels of Cx43, ZO-1 and Kir2.1 were measured by reverse transcriotion-polymerase chain reaction (RT-PCR) and Western blotting, respectively.

Results: In pinocembrin groups, heart rate (HR), mean arterial pressure (MAP) and rate-pressure product (RPP) levels were significantly higher compared with IR group $(p<0.05)$. Moreover, the extent of arrhythmia and the levels of CK-MB and CTnl in pinocembrin groups were lower relative to IR group, while $\mathrm{Na}^{+}-\mathrm{K}^{+}-$ATPase and $\mathrm{Ca}^{2+}-\mathrm{Mg}^{2+}$-ATPase activities, as well as Cx43 mRNA, ZO-1 mRNA, and protein levels of $\mathrm{Cx} 43, \mathrm{ZO}-1$ and Kir2.1 were significantly higher than the corresponding values for IR group $(p<0.05)$.

Conclusion: These results suggest that pinocembrin reduces ventricular arrhythmias in $I / R$ rats by upregulation of expressions of Cx43, ZO-1 and Kir21, and inhibition of re-distribution of ZO-1 and Cx43. These findings provide the basis for the clinical application of pinocembrin in the treatment of arrhythmia.
\end{abstract}

Keywords: Pinocembrin, Ventricular arrhythmia, Ligament junction protein, Recombinant human Kir2.1 protein, Arterial pressure, Protein levels, Claudin, Cardiomyocyte

\begin{abstract}
This is an Open Access article that uses a funding model which does not charge readers or their institutions for access and distributed under the terms of the Creative Commons Attribution License (http://creativecommons.org/licenses/by/4.0) and the Budapest Open Access Initiative (http://www.budapestopenaccessinitiative.org/read), which permit unrestricted use, distribution, and reproduction in any medium, provided the original work is properly credited.

Tropical Journal of Pharmaceutical Research is indexed by Science Citation Index (SciSearch), Scopus, International Pharmaceutical Abstract, Chemical Abstracts, Embase, Index Copernicus, EBSCO, African Index Medicus, JournalSeek, Journal Citation Reports/Science Edition, Directory of Open Access Journals (DOAJ), African Journal Online, Bioline International, Open-J-Gate and Pharmacy Abstracts
\end{abstract}

\section{INTRODUCTION}

Acute myocardial infarction is an important cause of sudden cardiac death. Early acute myocardial ischemia and myocardial injury can result in unstable electrical activity in the heart, as well as ventricular re-polarization, which may lead to malignant arrhythmia and sudden death [1]. Myocardial ischemia is mitigated by rapid and effective recovery, but myocardial ischemia and 
reperfusion can aggravate heart failure caused by ischemia and myocardial cell damage, leading to intracellular calcium overload, apoptosis and inflammatory reactions [2].

Pinocembrin, a major flavonoid derived from propolis, plays a role in the treatment of myocardial ischemia and reperfusion injury through its antioxidant effect, reduction of calcium overload, as well as inhibition of inflammation and myocardial cell apoptosis [3]. Consistent with its myocardial protective role, studies have demonstrated that pinocembrin reduced myocardial infarct area and the incidence of ventricular fibrillation in rats with ischemia reperfusion, and increased the expression of phosphorylation gap junction proteins in myocardial tissue [4]. However, the mechanism underlining the anti-myocardial ischemia reperfusion injury of pinocembrin has not been fully elucidated. Intracellular calcium overload is a key cause of arrhythmia. $\mathrm{Na}^{+}-\mathrm{K}^{+}-$ ATPase and $\mathrm{Ca}^{2+}-\mathrm{Mg}^{2+}$-ATPase play important roles in maintaining intracellular calcium homeostasis. It has been reported that the activities of $\mathrm{Ca}^{2+}-\mathrm{Mg}^{2+}-\mathrm{ATP}$ ase and $\mathrm{Na}^{+}-\mathrm{K}^{+}-$ ATPase decreased in arrhythmia patients $[5,6]$. The action potential in cardiomyocyte tissue takes place at gap junctions, and influences intercellular electrical coupling and impulse conduction. The main gap junction regulatory protein expressed in ventricular working muscle cells is Cx43 [7,8]. In myocardial pathology, the abnormal level of humoral factors affects the expression, transport and distribution of connexin; it changes the structure and function of gap junction, increases the rate of myocardial dislocation, and induces arrhythmia [9].

In this study, the effects of pinocembrin pretreatment on ventricular rhythm, and on the expression of cardiomyocyte ligament junction proteins ( $\mathrm{Cx} 43)$ and Claudin $1(\mathrm{ZO}-1)$, were determined in rat myocardium I/R model. This was with a view to unraveling the basis for its clinical use in the treatment of arrhythmia.

\section{EXPERIMENTAL}

\section{Animals and treatment}

Healthy 10-week-old male sprague dawley (SD) rats, weighing 350 - $400 \mathrm{~g}$ were used for this study. The rats were obtained from the Animal Experimental Center of the Chinese Academy of Medical Sciences in Beijing (SPF class animal laboratory, license number SYXK-2013-0025). The animals were provided feed and clean drinking water ad libitum during the acclimatization period, in line with experimental animal standards. The male SD rats were randomly divided into IR group, control group, and three graded pinocembrin dose groups (3, 10 and $30 \mathrm{mg} / \mathrm{kg}$ ).

I/R model was established as previously described [10]. The left anterior descending coronary artery was subjected to reperfusion for $30 \mathrm{~min}$. The rats were fixed in supine position, and anaesthetized intraperitoneally with $5 \%$ mebumalnatrium. This was followed by recording a normal II lead ECG to exclude abnormal rat. $\mathrm{HR}$, MAP, RPP were recorded $10 \mathrm{~min}$ before ischemia, 30 min after ischemia, and 30, 60, 120 min after reperfusion, to observe the arrhythmia. Rats in the three pinocembrin groups were injected intravenously at $10 \mathrm{~min}$ before ischemia. The IR and control groups received equivalent volume of saline. The animal experiments were approved by the Animal Ethic Committee of the Second Hospital of Hebei Medical University (approval ref no. 2015103) and were in compliance with the Principles of Laboratory Animal Care (NIH publication no. 83-23 revised 1985) [11].

\section{Chemicals and reagents}

Mebumalnatrium and pinocembrin were from Sigma (San Francisco, USA) and Chengdu Best Special Reagent Co., Ltd (Sichuan, China) respectively. The immunohistochemistry kits for CK-MB, cTnl (troponin), Cx43 and ZO-1 were purchased from Beijing Zhongjin Jinqiao Biotechnology Co., Ltd., Beijing, China. Trizol kits and reverse transcription kits were supplied by Invitrogen (Carlsbad, America). Rabbit anti-rat Cx43, ZO- 1, Kir2.1 monoclonal antibody, secondary antibody, and DAB kit were provided by Wuhan Boster Biological Engineering Co., Ltd., (Hebei, China). $\mathrm{Ca}^{2+}-\mathrm{Mg}^{2+}-\mathrm{ATP}^{2}$ ase and $\mathrm{Na}^{+}-$ $\mathrm{K}^{+}$-ATP use were provided by Nanjing Institute of Bioengineering, Jiangsu Province, China. Primers were synthesized by Shanghai Bioengineering Co., Ltd. (Shanghai, China).

\section{Assay of $\mathrm{Ca}^{2+}-\mathrm{Mg}^{2+}$-ATPase and $\mathrm{Na}^{+}-\mathrm{K}^{+}-$ ATPase activities}

The activities of $\mathrm{Ca}^{2+}-\mathrm{Mg}^{2+}-\mathrm{ATP}$ ase and $\mathrm{Na}^{+}-\mathrm{K}^{+}-$ ATPase in myocardial tissue were assayed spectrophotometrically in myocardial tissue homogenates as directed in the kit instructions. The protein contents of the homogenates were determined by Coomassie brilliant blue method.

Enzyme-linked immunosorbent assay (ELISA)

Serum levels of CK-MB and cTnl were determined by ELISA according to instructions in 
the ELISA kits. Absorbance was read at $450 \mathrm{~nm}$ in a microplate reader.

\section{Histological examination of myocardial tissue}

Myocardial tissue sections were processed for light microscopy. The tissues were immersed in paraformaldehyde and embedded in paraffin. Sections $(5 \mu \mathrm{m})$ were cut with microtome, stained with hematoxylin-eosin $(H \& E)$, and observed under the light microscope.

\section{Reverse transcription- polymerase chain reaction}

Total RNA was extracted from the myocardium and reverse-transcribed into cDNA. RT-PCR was performed according to Trizol and quantified by UV spectrophotometer. The primers used are shown in Table 1. The amplified product was analyzed three times by agarose gel electrophoresis. The relative expression was expressed as the ratio of the gray value of the gene to the GADPH gray value. BIO-RAD gel imaging system and Quantity OneV4.31 image analysis system were used for analysis.

\section{Immunohistochemistry}

The myocardial tissue of each rat was immersed in paraformaldehyde and made into 5- $\mu \mathrm{m}$ paraffin sections, and antigenized after dewaxing. Then, $\mathrm{H}_{2} \mathrm{O}_{2}$, primary antibody ( $\mathrm{Cx} 43$, ZO-1 1: 100/1: 100), polymer enhancers and enzyme-labeled anti-mouse/rabbit polymers were added in turn. The samples were then stained with $\mathrm{DAB}$, stained after re-dyeing, and sealed. The positive expression of $\mathrm{Cx} 43$ and ZO-1 in cardiomyocytes was analyzed by image-pro plus image. This involved selection of 5 different visual fields in the surrounding area of the tumor tissue under 40 magnification, and recording the number of positive expression cells in the field of view.

\section{Western blotting}

Total protein was separated by polyacrylamide gel electrophoresis. Then, poly (vinylidene fluoride) was used to derivatize the protein, followed by treatment with skim milk powder. Cx43, ZO-1 and Kir2.1 protein monoclonal antibody (1: 500 dilution) and GAPDH primary antibody (1: 1000 dilution) were added. The mixture was incubated overnight, and thereafter rinsed with TBST for $1 \mathrm{~h}$. Then GAPDH secondary antibody (1: 2000 dilution) was added. Finally, Quantity One image analysis software was used for the protein color band analysis in a dark room.

\section{Statistical analysis}

Measurement data were expressed as mean \pm standard deviation (SD). SPSS 19.0 was used for statistical analysis. Chi-square test was used to compare rates. Normality test was used to evaluate the measurement data. Multiple groups were compared by one-way ANOVA. Differences between groups were deemed statistically significant at $p<0.05$.

\section{RESULTS}

\section{Effect of pinocembrin pretreatment on hemodynamics and arrhythmia}

The levels of HR, MAP and RPP in I/R rats decreased with time in the three pinocembrin pretreatment groups $(p<0.05)$. However, the levels of HR, MAP and RPP in the control group and pinocembrin groups (3, 10 and $30 \mathrm{mg} / \mathrm{kg}$ ) were significantly higher, while the arrhythmia score was significantly lower than those in IR group $(p<0.05)$. The changes observed in the pinocembrin groups $(3,10$ and $30 \mathrm{mg} / \mathrm{kg}$ ) were dose-dependent. These results are shown in Table 2 and in Figure 1.

Table 1: Sequences of primers used

\begin{tabular}{cccc}
\hline Gene & Series (5'-3') & $\begin{array}{c}\text { Fragment size } \\
\text { (bp) }\end{array}$ \\
\hline \multirow{2}{*}{ Cx43 } & Upstream primer & GCGGCTTGCTGAGAACC & 295 \\
& Downstream primer & TTGCGGCACGAGGAATT & \\
\multirow{2}{*}{ Zo-1 } & Upstream primer & GCGCTGGAGAGAGACAAGAT & 179 \\
& Downstream primer & ATTGACGTTTCCCCACTCTG & \\
\multirow{2}{*}{ Kir2.1 } & Upstream primer & GGAGCGTGGCAACAGATAG & 167 \\
& Downstream primer & TCTCCCCCTTATTTGCTTCTTC & \\
GADPH & Upstream primer & TCCCTCAAGATTGTCAGCAA & 308 \\
& Downstream primer & AGATCCACAACGGATACATT & \\
\hline
\end{tabular}


Table 2: Effect of pinocembrin pre-treatment on hemodynamics in I/R rats

\begin{tabular}{|c|c|c|c|c|c|c|}
\hline Parameter & Group & $\begin{array}{c}\text { Before } \\
\text { Ischemia } \\
\left(10 \text { min; } T_{0}\right)\end{array}$ & $\begin{array}{l}\text { Ischemia (30 } \\
\left.\text { min; } T_{1}\right)\end{array}$ & $\begin{array}{c}\text { Reperfusion } \\
\left(30 \text { min; } T_{2}\right)\end{array}$ & $\begin{array}{l}\text { Reperfusion } \\
\left(60 \mathrm{~min} ; \mathrm{T}_{3}\right)\end{array}$ & $\begin{array}{l}\text { Reperfusion } \\
\left(120 \text { min; } T_{4}\right)\end{array}$ \\
\hline \multirow[t]{5}{*}{$\mathrm{MB}(\mathrm{mmHg})$} & Control & $120 \pm 11$ & $117 \pm 13$ & $123 \pm 15$ & $119 \pm 11$ & $113 \pm 8$ \\
\hline & IR & $116 \pm 12$ & $103 \pm 6^{* *}$ & $98 \pm 5^{* *}$ & $93 \pm 6^{\star *}$ & $92 \pm 10^{* *}$ \\
\hline & pinocembrin3 & $118 \pm 13$ & $106 \pm 9^{* *} \#$ & $101 \pm 6^{* *} \#$ & $98 \pm 7^{* *} \# \#$ & $94 \pm 12^{* *} \#$ \\
\hline & pinocembrin 10 & $121 \pm 11$ & 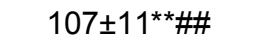 & $105 \pm 6^{* *} \# \#$ & $101 \pm 7 * \# \#$ & $101 \pm 12^{* * \# \# ~}$ \\
\hline & pinocembrin30 & $116 \pm 10$ & $110 \pm 18^{*} \# \#$ & $109 \pm 8^{*} \# \#$ & $105 \pm 10^{*} \# \#$ & 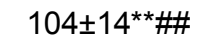 \\
\hline \multirow[t]{5}{*}{ HR (beats/min) } & Control & $420 \pm 29$ & $413 \pm 23$ & $405 \pm 23$ & $401 \pm 26$ & $394 \pm 23$ \\
\hline & IR & $417 \pm 17$ & $378 \pm 13^{* *}$ & $367 \pm 8^{* *}$ & $361 \pm 9^{* *}$ & $355 \pm 10^{\star * *}$ \\
\hline & Pinocembrin 3 & $423 \pm 23$ & $383 \pm 12^{\star *} \#$ & $372 \pm 10^{* *} \#$ & $366 \pm 11^{* *} \#$ & $359 \pm 12^{* *} \#$ \\
\hline & Pinocembrin 10 & $410 \pm 21$ & $391 \pm 14^{* *} \# \#$ & $385 \pm 12^{* *} \# \#$ & $379 \pm 13^{* *} \# \#$ & $371 \pm 15^{\star *} \# \#$ \\
\hline & Pinocembrin 30 & $411 \pm 19$ & $407 \pm 17^{*} \# \#$ & $399 \pm 18 * \# \#$ & $387 \pm 14^{*} \# \#$ & $383 \pm 17^{* *} \# \#$ \\
\hline \multirow{5}{*}{$\begin{array}{l}\text { RPP (beats/min } \\
\mathrm{mmHg} \text { ) }\end{array}$} & Control & $44057 \pm 2204$ & $43876 \pm 2134$ & $44323 \pm 2351$ & $44112 \pm 2495$ & $45213 \pm 3079$ \\
\hline & IR & $43077 \pm 1988$ & $36487 \pm 1892^{\star *}$ & $\underset{* *}{35427 \pm 1833}$ & $\underset{* *}{34437 \pm 2028}$ & $34751 \pm 1992^{* *}$ \\
\hline & Pinocembrin 3 & $42978 \pm 2301$ & $38645 \pm 1983^{\star *} \# \#$ & $\begin{array}{c}38121 \pm 1936 \\
\star \star \# \#\end{array}$ & $\begin{array}{c}35983 \pm 1672 \\
* \star \#\end{array}$ & $\begin{array}{c}35723 \pm 1687^{* *} \\
\#\end{array}$ \\
\hline & Pinocembrin 10 & $43659 \pm 1890$ & $40127 \pm 2012^{* *} \# \#$ & $\begin{array}{c}38961 \pm 1856 \\
\star \star \# \#\end{array}$ & $\begin{array}{c}37624 \pm 1692 \\
* \star \# \#\end{array}$ & $\begin{array}{c}37743 \pm 1769^{* *} \\
\# \#\end{array}$ \\
\hline & pinocembrin 30 & $42355 \pm 2140$ & $42521 \pm 1780^{* *} \# \#$ & $\begin{array}{l}\text { 41262士1916 } \\
\text { **\#\# }\end{array}$ & $\begin{array}{l}40256 \pm 1777 \\
\star \star \# \#\end{array}$ & $\begin{array}{l}41980 \pm 1899^{* *} \\
\# \#\end{array}$ \\
\hline
\end{tabular}

Note: Compared with control, ${ }^{*} p<0.05 ;{ }^{* *} p<0.01$; vs IR,\#p<0.05,\#p<0.05

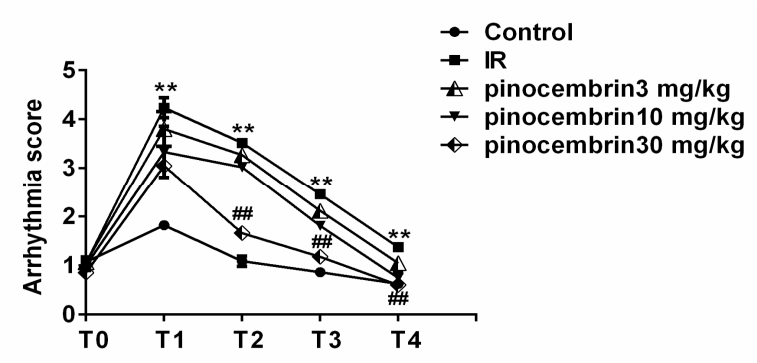

Figure 1: Effect of pinocembrin pretreatment on arrhythmia score in I/R rats. ${ }^{*} p<0.05 ;{ }^{* *} p<0.01$ compared with control; \#p<0.05,\#\#< $\quad \# .05$ compared with IR

\section{Effect of pinocembrin pre-treatment on $\mathrm{Na}^{+}$. $\mathrm{K}^{+}$-ATPase and $\mathrm{Ca}^{2+}-\mathrm{Mg}^{2+}$-ATPase levels}

The levels of $\mathrm{Na}^{+}-\mathrm{K}^{+}-\mathrm{ATP}$ ase and $\mathrm{Ca}^{2+}-\mathrm{Mg}^{2+}-$ ATPase in the control group were higher than their corresponding levels in the other four groups, while those in the pinocembrin groups (3, $10,30 \mathrm{mg} / \mathrm{kg}$ ) were higher than values in IR group $(p<0.05)$. These changes were dosedependent, as shown in Figure 2.
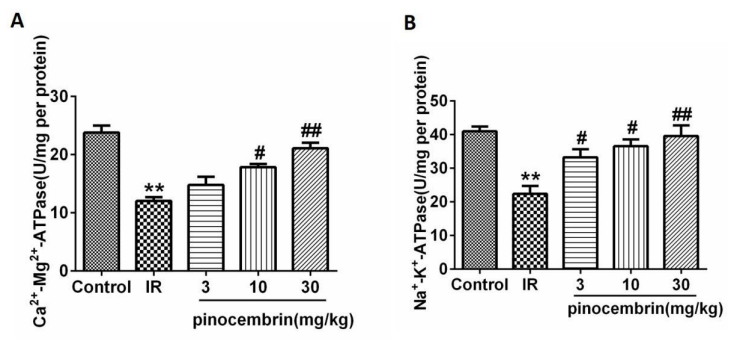

Figure 2: Effect of pinocembrin on activities $\mathrm{Ca}^{2}+$ $\mathrm{Mg}^{2}+-\mathrm{ATP}$ ase and $\mathrm{Na}+-\mathrm{K}+-\mathrm{TPase}$ in myocardial tissue. (A) $\mathrm{Ca}^{2+}-\mathrm{Mg}^{2+}-\mathrm{ATPase}$ (B) $\mathrm{Na}^{+}-\mathrm{K}^{+}-\mathrm{ATPase}$; ${ }^{*} p$ $<0.05,{ }^{* *} p<0.01$ compared with control; $\# p<0.05$, $\#$ \# $<0.01$ compared with IR

\section{Effects of pinocembrin pretreatment on the expression of CK-MB and CTnI in I/R rats}

The levels of CK-MB and cTnl in IR group and pinocembrin groups $(3,10,30 \mathrm{mg} / \mathrm{kg})$ were significantly higher than those in the control group, while their levels in the IR group were significantly and dose-dependently higher than in the three pinocembrin groups (Figure 3).
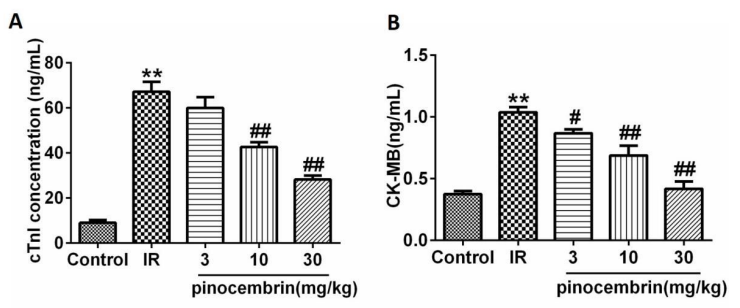

Figure 3: Effect of pinocembrin on serum concentrations of CK-MB and cTnl. (A) CTnl. (B) CK$\mathrm{MB} ;{ }^{*} p<0.05,{ }^{* *} p<0.01$ compared with control; \#p< $0.05, \#$, $<0.01$ compared with IR

\section{Histopathological changes in myocardial tissue}

The rats in the control group had no myocardial abnormalities; the arrangement of myocardial fibers was neat and normal (Figure 4). On the other hand, the myocardial fibers in the IR group were disordered, and were infiltrated by inflammatory cells. The myocardium of the 
pinocembrin group was significantly and dosedependently improved, when compared with the IR group.

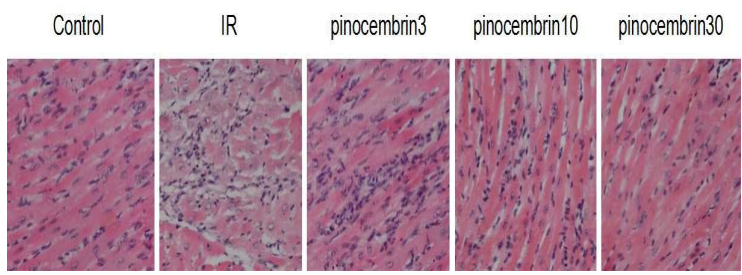

Figure 4: Photomicrograph of myocardial tissues of rats in the various groups $(H \& E, \times 200)$

\section{Effect of pinocembrin on expressions of Cx43, ZO-1 and Kir2.1 mRNA in I/R rats}

The results in Figure 5 show that the control group had significantly higher levels of Cx43, ZO1 and Kir2.1 mRNA than in the IR group, while values of these parameters in the pinocembrin groups (3, 10 and $30 \mathrm{mg} / \mathrm{kg}$ ) were significantly and dose-dependently higher than in the IR group $(p<0.05)$.
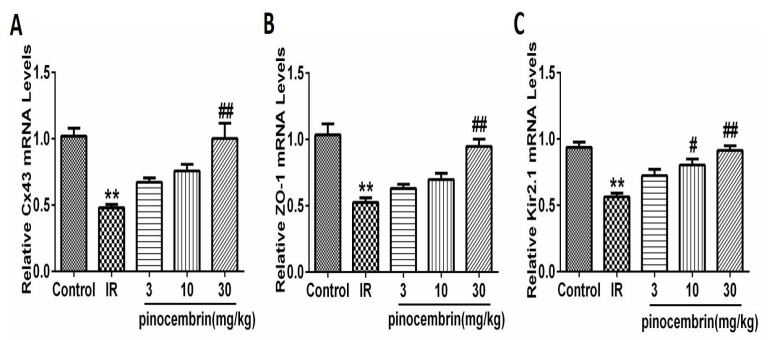

Figure 5: Effect of pinocembrin on levels of Cx43, ZO1 and Kir2.1 mRNA in I/R rats. (A) Cx43. (B) Kir2.1 mRNA. (C) ZO-1; ${ }^{*} p<0.05,{ }^{* *} p<0.01$; vs IR, \#p< $0.05, \# p<0.01$ copare with control

Effect of pinocembrin pretreatment on distribution of Cx43 and ZO-1 proteins in I/R rats

The expression of $\mathrm{Cx} 43$ and ZO-1 proteins in the control group was strongly positive. The proteins were distributed mostly in the long axis of myocardial fibers or the side-side junction or cytoplasm of the cardiomyocytes, with a few in the intercalary disk. In the IR group, there were decreases in the expressions of $\mathrm{Cx} 43$ and ZO-1 proteins, and the proteins were unevenly distributed. There were some dose-dependent improvements in the expression of histone in the pinocembrin groups $(3,10$ and $30 \mathrm{mg} / \mathrm{kg})$. These results are shown in Figure 6.

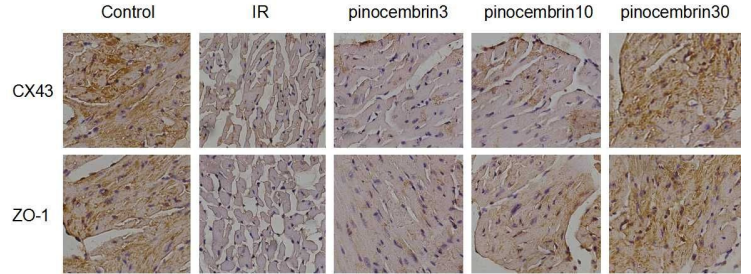

Figure 6: Effect of pinocembrin on the protein expressions of $\mathrm{Cx} 43$ and $\mathrm{ZO}-1$ in the myocardium of I/R rats $(\times 200)$

Effects of pinocembrin pretreatment on expression of Cx43, ZO-1 and Kir2.1 proteins in I/R rats

The expressions of Cx43, ZO-1 and Kir2.1 proteins were strongly positive in the control group, but were decreased in IR group (Figure 7). The expressions of those proteins in control group were higher than in the IR group, and dose-dependently higher in the pinocembrin groups than in the IR group.
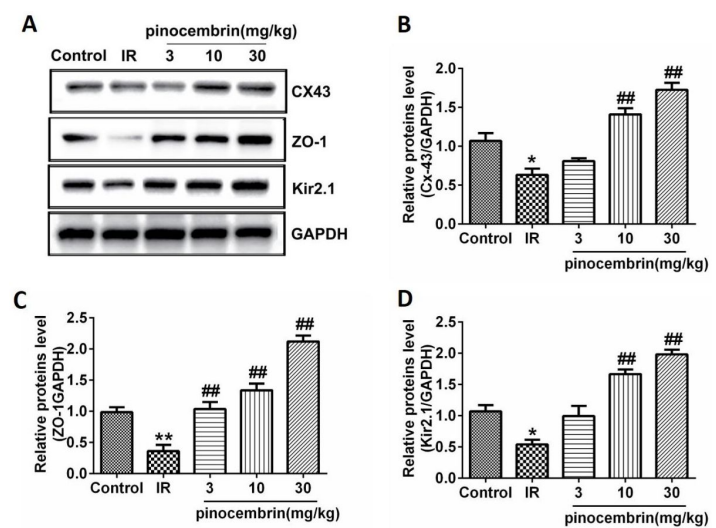

Figure 7: Effect of pinocembrin on the expressions of Cx43, ZO-1 and Kir2.1 proteins in I/R rats; ${ }^{*} p<0.05$,

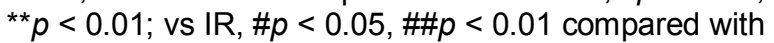
control

\section{DISCUSSION}

Myocardial ischemia may cause degeneration and necrotic dissolution of cardiomyocytes. Reperfusion injury increases membrane permeability of cardiomyocytes and levels of myocardial injury markers in blood. The degree of myocardial injury is related to levels of CK-MB and CTnl $[12,13]$. In this study, the serum levels of CK-MB and CTnl in the ischemia-reperfusion model were significantly higher than those in the control group, but significantly decreased in the pinocembrin pretreatment groups. These results suggest that pretreatment with pinocembrin can relieve myocardial ischemia-reperfusion injury in rats. 
The pathogenesis of arrhythmia is not yet fully elucidated. However, studies have indicated that it may be associated with degeneration of conductive fibers and autonomic cells, abnormal ion channels, vagal tone abnormalities, and ion transport on both sides of cardiomyocytes [14]. $\mathrm{Na}^{+}-\mathrm{K}^{+}$-ATPase is a transmembrane, ATP-driven ion pump which is responsible for transmembrane transport of $\mathrm{Na}^{+}$and $\mathrm{K}^{+}$. It maintains electrochemical gradient across the cell membrane through asymmetric distribution of $\mathrm{Na}^{+}$and $\mathrm{K}^{+}$across the membrane. The main function of $\mathrm{Ca}^{2+}-\mathrm{Mg}^{2+}$-ATPase is to actively transport $\mathrm{Ca}^{2+}$ into the sarcoplasmic reticulum from the cytoplasm. This result could be attributed to the release of $\mathrm{Ca}^{2+}$ obstacles in calcium pool which caused the reduction of $\mathrm{Ca}^{2+}$ permeability in sarcoplasmic reticulum and the calcium flow reduced consequently, leading further to deceleration of spontaneous depolarization of sinus node pacing cells.

Ultimately, slow arrhythmia can be induced. $\mathrm{Na}^{+}-$ $\mathrm{K}^{+}$-ATPase, $\mathrm{Ca}^{2+}-\mathrm{Mg}^{2+}$-ATPase are involved in cardiomyocyte membrane ion channels and ion transport [15]. Ion transport on both sides of the cardiomyocyte membrane is the basis of generation of action potential. Abnormalities in cardiac ion channels are the main causes of slow arrhythmia [16]. The results of this study show that pretreatment with pinocembrin can significantly enhance the activities of $\mathrm{Na}^{+}-\mathrm{K}^{+}$ATPase and $\mathrm{Ca}^{2+}-\mathrm{Mg}^{2+}$-ATPase in myocardium of ischemia-reperfusion rats. This implies that the drug can maintain normal $\mathrm{Na}^{+}$and $\mathrm{K}^{+}$ion concentration gradient and electrochemical gradient needed for normal cellular energy metabolism. Cx40, Cx43 and Cx45 are the gap junction proteins in human tissue. Cx43 is the main connexin of cardiomyocytes. It is encoded by GJA1 gene cluster at the junction of cardiomyocytes; it maintains communication between cells, energy exchange and transmission of chemical information.

Decreased expression of $\mathrm{Cx} 43$ results in prolonged duration of action potential and repolarization process, leading to blockage of conduction. Cx43 plays important roles in the normal development of the heart, and is also involved in the synchronization of electrical activity of the body and the coordination of secretion [17]. Abnormal expression and distribution of Cx43 lead to decreased electrical coupling and intercellular conduction, and induction of re-entrant arrhythmia.

It has been shown that the heart structure and systolic function of homozygous mice with knockout $\mathrm{Cx} 43$ gene were normal, but after two months the rats developed spontaneous ventricular arrhythmias and died [18]. The use of gene therapy to increase the expression of $\mathrm{Cx} 43$ can exert a protective effect against fatal arrhythmia [19]. The structure and function of Cx43 in the gap junction of the myocardium are closely related to arrhythmia.

The cardiac inwardly rectifying $\mathrm{K}$ current $\left(I_{\mathrm{K} 1}\right)$ mediated by Kir2.1 protein maintains the stability of resting membrane potential. This protein is produced by chromosome 17 in KCNJ2 gene. Dysfunctional or decreased expression of Kir2.1 protein significantly reduces the action potential, leading to rapid repolarization of the current intensity, extension of QT interval and duration of action potential, and arrhythmia [20]. ZO-1 is coupled to $\mathrm{Cx} 43$ at the intercalation disk by binding to the Cx43 carboxyl terminus, thereby anchoring the Cx43 at the intercalation disk [21]. In the present study, the expression of ZO-1 was decreased in myocardial ischemia-reperfusion, Cx43 was intercalated with ZO-1, and Cx43 and ZO-1 were redistributed, leading to calcium overload and arrhythmia. The expressions of Cx43 and Kir21 proteins decreased in the myocardium of IR group, and were significantly lower than corresponding values in the pinocembrin group.

The up-regulation of $\mathrm{Cx} 43$ and Kir2.1 proteins was related to the expressions of their respective encoding genes GJA1 and KCNJ2. A variety of factors influence the opening and closing of gap junctions. These include intracellular $\mathrm{Ca}^{2+}$ levels, intracellular cytosolic $\mathrm{pH}$, cross-channel voltage, and the phosphorylation status of gap junction protein [22]. Decreases in intracellular $\mathrm{Ca}^{2+}$ levels lead to decreases in electrical conduction in gap junctions. Pinocembrin exerted an antiarrhythmic effect by increasing the activity of $\mathrm{Ca}^{2+}-\mathrm{Mg}^{2+}$-ATPase, thereby maintaining cardiac channels and upregulating the expression of Cx43 protein.

\section{CONCLUSION}

The results obtained in the present study suggest that pre-treatment with pinocembrin can alleviate arrhythmia in rats with myocardial ischemia and reperfusion. The mechanism of action of this drug is related to enhancement of $\mathrm{Na}^{+}-\mathrm{K}^{+}-$ ATPase and $\mathrm{Ca}^{2+}-\mathrm{Mg}^{2+}$-ATPase activities; upregulation of protein expressions of $\mathrm{Cx} 43, \mathrm{ZO}-1$ and Kir2.1, and suppression of the redistribution of ZO-1 and Cx43. The specific mechanism of regulation of $\mathrm{Cx} 43$, ZO-1 and Kir2.1 proteins may be related to expressions of GJA1 and KCNJ2 genes. These findings provide the basis for the clinical application of pinocembrin in the treatment of arrhythmia. 


\section{DECLARATIONS}

\section{Conflict of Interest}

No conflict of interest is associated with this work.

\section{Contribution of authors}

We declare that this work was done by the authors named in this article and all liabilities pertaining to claims relating to the content of this article will be borne by the authors.

\section{REFERENCES}

1. Merghani A, Maestrini V, Rosmini S, Cox AT, Dhutia $H$, Bastiaenen R, David S, Yeo TJ, Narain R, Malhotra A. Prevalence of Subclinical Coronary Artery Disease in Masters Endurance Athletes with a Low Atherosclerotic Risk Profile. Circulation 2017; PMID: 28465287.

2. Vora A, Naik A, Lokhandwala Y, Chopra A, Varma J, Wander GS, Jaswal A, Srikanthan V, Singh B, Kahali D. Profiling cardiac arrhythmia and heart failure patients in India: The Pan-arrhythmia and Heart Failure Observational Study. Indian Heart J 2011; 69(2): 226239.

3. Saad MA, Abdel Salam RM, Kenawy SA, Attia AS. Pinocembrin attenuates hippocampal inflammation, oxidative perturbations and apoptosis in a rat model of global cerebral ischemia reperfusion. Pharmacol Rep 2015; 67(1): 115-122.

4. Lungkaphin A, Pongchaidecha A, Palee S, Arjinajarn $P$, Pompimon $W$, Chattipakorn $N$. Pinocembrin reduces cardiac arrhythmia and infarct size in rats subjected to acute myocardial ischemia/reperfusion. Appl Physiol Nutr Metab 2015; 40(10): 1031-1037.

5. Ni M, Ruan L, Zhang C. Antiarrhythmic peptide AAP10 prevents arrhythmias induced by protein kinase $C$ activation in rabbit left ventricular wedges. Int Heart $J$ 2015; 56(2): 234-238.

6. Fanton $Y$, Robic $B$, Rummens JL, Daniels $A$, Windmolders S, Willems L, Jamaer L, Dubois J, Bijnens $E$, Heuts N. Cardiac atrial appendage stem cells engraft and differentiate into cardiomyocytes in vivo: $A$ new tool for cardiac repair after MI. Int J Cardiol 2015; 201: 1019

7. Aiba T, Noda T, Hidaka I, Inagaki M, Katare RG, Ando M, Sunagawa K, Sato T, Sugimachi M. Acetylcholine Suppresses Ventricular Arrhythmias and Improves Conduction and Connexin-43 Properties during Myocardial Ischemia in Isolated Rabbit Hearts. J Cardiovasc Electrophysiol 2015, 26(6): 678-685.

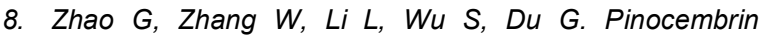
protects the brain against ischemia-reperfusion injury and reverses the autophagy dysfunction in the penumbra area. Molecules 2014; 19(10): 15786-15798.
9. Rampazzo A, Calore $M$, van Hengel J. Intercalated discs and arrhythmogenic cardiomyopathy. Circ Cardiovasc Genet 2014; 7(6): 930-940.

10. Horvat $D$, Vincelj J. Impact of reperfusion therapy and infarct localization on frequency of premature ventricular beats in acute myocardial infarction. Med Glas (Zenica) 2015, 12(2): 139-143.

11. Institute of Laboratory Animal Resources (US). Committee on Care, Use of Laboratory Animals, National Institutes of Health (US). Division of Research Resources. Guide for the care and use of laboratory animals[M]. National Academies, 1985.

12. Grippo AJ, Moffitt JA, Henry MK, Firkins R, Senkler J, McNeal N, Wardwell J, Scotti MA, Dotson A, Schultz R.. Altered Connexin 43 and Connexin 45 protein expression in the heart as a function of social and environmental stress in theprairie vole. Stress 2015; 18(1): 107-114.

13. Gao J, Zhao Y, Wang Y, Xin J, Cui J, Ma S, Lu F, Qin L, $Y u X$. Anti-arrhythmic effect of acupuncture pretreatment in the rats subjected to simulative global ischemia and reperfusion--involvement of intracellular $\mathrm{Ca} 2+$ and connexin 43. BMC Complement Altern Med 2015; 15: 5.

14. Patil KD, Halperin HR, Becker LB. Cardiac arrest: resuscitation and reperfusion. Circ Res 2015; 116(12): 2041-2049.

15. $W u T, W u D, W u Q$, Zou B, Huang $X$, Cheng $X, W u Y$, Hong $K$, Li P. Effect and mechanism of Irbesartan on occurrence of ventricular arrhythmias in rats with myocardial ischemia through connexin43 (cx43). Asian Pac J Trop Med 2016; 9(10): 1007-1012.

16. Wang $M$, Shan J, Yang $Q$, Ma X, Jin S, Guo X, You $Q$, Tang Y. Antiarrhythmic efficacy of CPUY102122, a multiple ion channel blocker, on rabbits with ischemia/reperfusion injury. Pharmacol Rep 2014; 66(6): 1022-1030.

17. Seki A, Nishii K, Hagiwara N. Gap junctional regulation of pressure, fluid force, and electrical fields in the epigenetics of cardiac morphogenesis and remodeling. Life Sci 2015; 129: 27-34.

18. Chojnacka K, Brehm R, Weider K, Hejmej A, Lydka M, Kopera-Sobota I, Bilinska B. Expression of the androgen receptor in the testis of mice with a Sertoli cell specific knock-out of the connexin 43 gene (SCCX43KO(-/-)). Reproductive Biol 2012; 12(4): 341.

19. Santos-Almeida FM, Girão $H$, da Silva CA. Cholinergic stimulation with pyridostigmine protects myocardial infarcted rats against ischemic-induced arrhythmias and preserves connexin43 protein. Am J Physiol Heart Circ Physiol 2015; 308(2): H101-H107.

20. Siragam V, Cui $X$, Masse S, Ackerley C, Aafaqi S, Strandberg L, Tropak M, Fridman MD, Nanthakumar K, Liu J. TMEM43 mutation p.S358L alters intercalated disc protein expression and reduces conduction velocity in arrhythmogenic right ventricular cardiomyopathy. PLoS One 2014; 9(10): e109128.

21. Shin SY, Jo WM, Min TJ, Kim BK, Song DH, Hyeon SH, Kwon JE, Lee WS, Lee KJ, Kim SW. Gap junction 
remodelling by chronic pressure overload is related to the increased susceptibility to atrial fibrillation in rat heart. Europace 2015; 17(4): 655-663.

22. Lorenz M, Hellige N, Rieder P, Kinkel HT, Trimpert C, Staudt A, Felix, SB, Baumann G, Stangl K, Stangl V.
Positive inotropic effects of epigallocatechin-3-gallate (EGCG) involve activation of $\mathrm{Na}+/ \mathrm{H}+$, and $\mathrm{Na}+\mathrm{Ca} 2+$, exchangers. Euro J Heart Failure, 2008; 10(5): 439445. 